\title{
PRACTICAL POTENTIAL OF GRAIN IMPURITIES IN THE PROCESSING OF SUNFLOWER OIL RAW MATERIALS IN THE OIL AND FAT INDUSTRY
}

Yevhen Mykhailov ${ }^{a^{*}}$, Natalia Zadosna ${ }^{\mathrm{a}}$, Yevhen Ihnatieva ${ }^{\mathrm{a}}$, Anastasiia Kutsenko ${ }^{\mathrm{b}}$,

Taras Hutsol ${ }^{c}$, Katarzyna Grotkiewicz ${ }^{\mathrm{d}}$, Yuriy Firman ${ }^{\mathrm{e}}$, Iryna Horetska ${ }^{\mathrm{f}}$

a Department of Machine Use in Agriculture, Dmytro Motornyi Tavria State Agrotechnological University in Melitopol, e-mail: evgenii19508@gmail.com, ORCID 0000-0001-9906-6699; e-mail: geleantus2017@gmail.com, ORCID 0000-0001-7780-235X; e-mail: yevhen.ihnatiev@tsatu.edu.ua, ORCID 0000-0003-0315-1595

b Department of Mechanics Faculty of Construction and Design National University of life and environmental sciences of Ukraine; ORCID 0000-0003-1808-6773, e-mail: kutsenko@ nubip.edu.ua

c Department of Mechanics and Agroecosystems Engineering, Polissia National University, 10-008, Zhytomyr, Ukraine, e-mail: wte.inter@gmail.com, ORCID 0000-0002-9086-3672

d Department of Production Engineering, Logistics and Applied Computer Science, University of Agriculture in Krakow, Krakow, Poland, katarzyna.grotkiewicz@urk.edu.pl, ORCID 0000-0001 $-8564-0928$

e Faculty of Engineering and Technology, Higher Educational Institution "Podillia State University", Kamianets-Podilskyi, Ukraine, e-mail: yuriu.firman@gmail.com, ORCID 0000-0001-5267-4902

f LLC “360-EkoTech Company”, Bydgoszcz, Poland, e-mail: goreckaya.ira@gmail.com, ORCID 0000-0002-3639-9784

*Corresponding author: e-mail: yevhen.ihnatiev@tsatu.edu.ua

\begin{tabular}{l}
\hline ARTICLE INFO \\
\hline Article history: \\
Received: November 2021 \\
Received in the revised form: \\
December 2021 \\
Accepted: January 2022 \\
\hline Keywords: \\
practical potential, \\
oil and fat industry, \\
sunflower oil raw materials, \\
grain impurities, \\
fuels. \\
\end{tabular}

\section{ABSTRACT}

The analysis of statistical data showed that a large amount of plant waste is generated annually in oil and fat production plants, which must be processed and reused. The paper analyzes the problems of reusing sunflower oil production waste, which is characterized by a relatively high energy value: 1 ton of plant waste is equivalent to 0.625 tons of conventional fuel. According to the mathematical estimation, the actual total amount of impurities is $7.29 \%$, in which major impurities constitute $25.7 \%$. Studies have shown a high probability of oil - containing impurities $-37.25 \%$. Therefore, it is recommended to process such impurities into fuel briquettes and technical oil to increase the profitability of sunflower oil production. For example, at the annual load of technological equipment of the Melitopol Oil Extraction Plant, in 250 days, at a daily processing capacity of $550 \mathrm{t} \cdot \mathrm{day}^{-1}$, an annual profit of 560,000 EUR is obtainable from the sunflower grain impurities processed into fuel and technical oil.

\section{Introduction}

The global lack of fossil energy resources in developed countries leads to the expansion of efficient use of alternative energy sources. Along with the use of solar and wind energy, 
biofuels, various solid organic materials, and biogas, the use of agricultural products is becoming more widespread (Tryhuba et al., 2020). Prospects for non - food use of the latter also follows from the analysis of the dynamics of prices for energy, as well as industrial and agricultural products (Tryhuba et al., 2021, Korys et al., 2019).

Agricultural production turns from a consumer of traditional energy sources into a producer with significant potential for the future. Currently, three main global trends can be observed in the development of rural bioenergy can be observed (Mikhailov et al., 2019):

- reduction of total energy consumption;

- increasing the use of renewable energy sources;

- predominant use of solid biofuels.

A promising direction is the use of biomass in heating technological units, especially in dryers. Using heat generators that run on organic waste shows high profitability of such technologies (Yermakov et al., 2021). On the other hand, efficient use of energy boilers requires the development of biofuel preparation technologies, automatic combustion process control systems and special materials of the combustion chamber (Sumets, 2016).

Particular attention should be paid to the choice of recycling technology and equipment, which determine the amount of capital expenditures. Minimization of these costs is possible due to modernization of existing power units at the plants, retrofitting the design of the combustion chamber and the corresponding gas purification constructions. Foreign experience in the use of plant waste as an energy raw material testifies to the effectiveness of the search for alternative fuels (Szufa et al., 2020). For this purpose, various types of fuel solutions for the incineration of plant waste have been developed, in briquetted, crumbly, or granular form (Dziedzic et al., 2021).

The analysis of statistical data showed that at the agro-processing Centers (APC) a large amount of plant waste is generated annually. his waste type is characterized by relatively high energy value, as 1 ton of vegetable waste is equivalent to $0.625 \mathrm{t}$ of conventional fuel. Therefore, plant waste can be considered an important potential fuel for the development of small power engineering in agricultural areas. Thus, compared to other types, the energy use of plant waste is the most accessible, economically effective, and also has ecological and social and economic advantages (Mykhailov, 2020).

Among all waste types generated during the processing of agricultural raw materials, sunflower husk poses a special problem. It requires large storage areas due to its low bulk density and special storage conditions due to its fire-hazardous properties. Processing sunflower husk to fuel is quite a new task for Ukrainian producers and in this work is the object of study. Some practical experience has already been obtained in the production of fuel pellets and briquettes from sunflower husk has already been obtained, however, not without challenges. On the other hand, comparison of the composition of sunflower husk combustion products against traditional coal have shown that the sulfur content in the ash residue of the husk is $0.1-0.2 \%$, which is $10-20$ times less compared to coal. Therefore, from the point of view of environmental protection, sunflower husk is a more environmentally friendly fuel than coal.

Ukraine has the most favorable conditions in terms of oilseed production; it is one of the country's main areas of agricultural production. Last year, oilseeds occupied almost $30 \%$ of 26.7 million hectares of arable land, and the share of oilseeds in the structure of crops remained unchanged (Kharchenko et al., 2019). 
Practical potential...

The foundation of Ukrainian production of oilseeds is sunflower. Its share in the total production of this group of crops is almost two thirds and has been steadily increasing in recent years (Kovalenko et al., 2021, Mykhailov, 2020). This requires an objective assessment of industry development and increasing its efficiency in the new economic environment. Therefore, the main purpose of the article is to determine the economic potential of the use of sunflower seed processing waste from sunflower oil production in a oil and fat processing plant.

\section{Materials and Methods}

Previous studies have shown that over the past five years, i.e., from 2015 to 2019, Ukrainian companies have significantly increased the processing of sunflower oil raw material. This has led to a proportional increase in the generation of industrial waste, especially sunflower seed husk. The volume of sunflower oil processing in the oil and fat industry (OFI) is summarized in Table 1 (Mikhailov and Zadosna, 2015; Mikhailov et al., 2016).

Previous studies of OFI enterprises revealed that the greatest attention was paid to the processing of industrial waste into fuel materials (granulated husk, husk pellets and fuel briquettes) at Zaporizhzhya Oil and Fat Plant (OFP), Vinnytsia OFP, Vovchansky Oil Extraction Plant (OEP). In 2015, these plants significantly increased the production of fuels compared to 2019.

Table 1.

The volume of processing of sunflower oil raw materials at OFI enterprises.

\begin{tabular}{lccccc}
\hline & \multicolumn{5}{c}{ Volume of processing, in thousand tons } \\
\cline { 2 - 6 } List of enterprises & 2015 & 2016 & 2017 & 2018 & 2019 \\
\cline { 2 - 6 } Melitopol OEP & 122947 & 136394 & 116688 & 117870 & 131338 \\
Prikolotnyansky OEP & 100721 & 127299 & 149541 & 97013 & 117720 \\
Vovchansky OEP & 318939 & 292165 & 339864 & 295826 & 345655 \\
Dniprovsky OEP & 364312 & 483029 & 483465 & 487231 & 492636 \\
Chernivtsi OFP & 141894 & 121491 & 143181 & 114730 & 116250 \\
Vinnytsia OFP & 595684 & 579561 & 648937 & 594609 & 525053 \\
\hline
\end{tabular}

The results of the analysis of the sunflower oil production process in specialized Ukrainian enterprises show that the share of husk in the processing of relevant raw materials is quite significant. According to sources (Mikhailov and Zadosna, 2015; Mikhailov et al., 2016) in the years $2015-2019$, husk waste averaged $14.5-15.0 \%$ of the total sunflower seed processed in the studied companies (Table 2). 
Yevhen Mykhailov et al.

Table 2 .

The amount of waste (husk) in the processing of sunflower seeds at the studied enterprises.

\begin{tabular}{llllll}
\hline \multirow{2}{*}{ List of enterprises } & \multicolumn{5}{c}{ The amount of husk formation, \% } \\
\cline { 2 - 6 } & 2015 & 2016 & 2017 & 2018 & 2019 \\
\cline { 2 - 6 } Melitopol OEP & 17.89 & 17.44 & 18.30 & 17.11 & 17.41 \\
Prikolotnyansky OEP & 18.10 & 17.90 & 17.80 & 19.18 & 19.42 \\
Vovchansky OEP & 17.48 & 17.54 & 16.80 & 18.58 & 18.68 \\
Dniprovsky OEP & 15.56 & 15.15 & 15.50 & 16.33 & 15.92 \\
Chernivtsi OFP & 16.75 & 16.49 & 16.74 & 16.02 & 15.70 \\
Vinnytsia OFP & 16.45 & 16.30 & 16.62 & 16.34 & 16.58 \\
\hline
\end{tabular}

However, please note that the disposal process at these enterprises needs to be urgently improved in order to reduce the cost of its implementation (Sumets, 2016). The above proves that such enterprises have vast opportunities for organization of efficient utilization of industrial waste, which will increase their efficiency and allow Ukraine to increase energy security.

Experimental studies of the fractional composition of sunflower oil raw materials allowed us to determine its statistical characteristics.

The source material quality coming to the enterprise from agricultural producers is determined by the analysis results of the samples (Chernyakov et al., 2021; Choszcz et al., 2020; Konopka et al., 2017).

A total of 60 samples of grain material were taken according to the method (Mikhailov and Zadosna, 2015). The percentage was determined for:

1. Full-fledged seeds $-M_{n p},(\%)$

2. Oil content impurity $-m_{o d},(\%)$

3. Major grain impurities $-m_{k d},(\%)$

4. Fraction passing through a $3 \mathrm{~mm}$ sieve $-m_{p s},(\%)$

5. Minor impurities $-m_{l d},(\%)$

6. Grain impurity $-m_{c d},(\%)$

7. Grain purity $-H,(\%)$

\section{Results and discussion}

As a result of field research to determine the statistical characteristics of sunflower oil raw materials at the Melitopol oil extraction plant (MOEZ), qualitative indicators of sunflower oil raw materials arriving from different regions of Ukraine were studied. The results are shown in Table 3 (Mikhailov et al., 2016).

According to the test results, the authors determined the mathematical estimation value $-m$, the maximum $-(\max )$ and the minimum $-(\min )$ of impurities, the standard deviation $-\sigma$ and the coefficient of variation $-v$. 
Practical potential...

Table 3.

Summary of results of field research to determine statistical characteristics of sunflower oil raw materials.

\begin{tabular}{|c|c|c|c|c|c|c|c|}
\hline$\dot{z}$ & 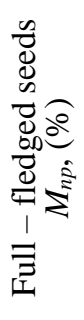 & 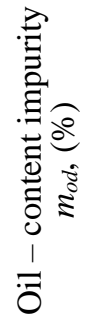 & 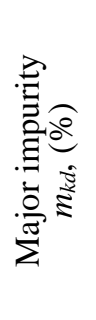 & 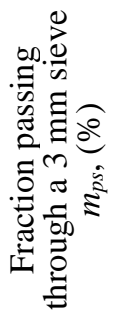 & 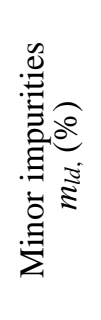 & 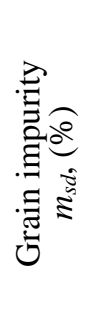 & 昰 \\
\hline$m$ & 88.5 & 4.35 & 2.9 & 4.23 & 0.06 & 7.23 & 92.76 \\
\hline $\min$ & 68.7 & 0.76 & 0.7 & 0.3 & 0.01 & 2.1 & 84.6 \\
\hline $\max$ & 96.8 & 11.27 & 6.0 & 19.1 & 0.15 & 22.48 & 97.1 \\
\hline$\sigma$ & 5.07 & 2.37 & 1.75 & 3.19 & 0.03 & 3.77 & 3.77 \\
\hline$v$ & 5.73 & 54.41 & 58.49 & 75.59 & 59.47 & 52.2 & 4.07 \\
\hline
\end{tabular}

The analysis of full-fledged seeds in the source material (Table 3, Fig. 1), shows that their highest percentage was $M_{n p(\max )}-96.8 \%$ with a mathematical estimation of $M_{n p(\mathrm{sr})}-88.5 \%$, and the minimum value $M_{n p(\min )}-68.7$. In this case, the standard deviation $\sigma$ was $5.07 \%$, and coefficient of variation $v-5.73 \%$ (Mikhailov and Zadosna, 2015).

In terms of oil content impurity $m_{o d}$, further processing is required within first 24 hours. When used for long-term storage as a production reserve, this impurity must be removed from the sunflower heap.

According to the results of field tests, the oil content impurity $m_{o d}$ in the raw material (Table 3, Fig. 2) was $4.35 \%$, according to the mathematical estimation $m_{o d(\mathrm{sr})}$, while the maximum value of $m_{o d(\max )}$ was $11.27 \%$, the minimum value of $m_{o d(\min )}-0.76 \%$, the standard deviation $\sigma-2.37 \%$ and a coefficient of variation $v-54.41 \%$.

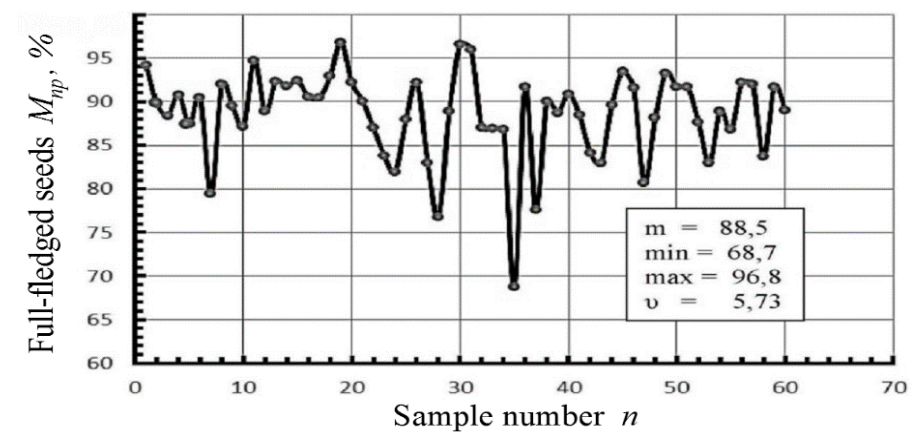

Figure 1. Statistical characteristics of full-fledged seeds 


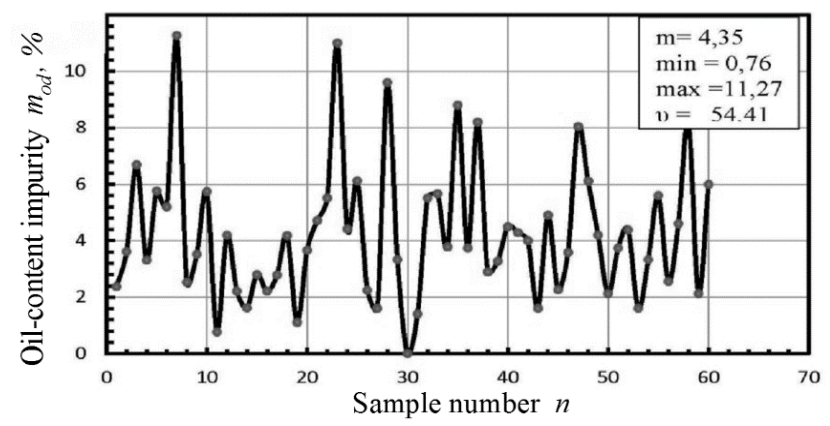

Figure 2. Statistical characteristics of oil content impurity

The coefficient of variation has a fairly high value, indicating quite a broad range of oil impurities in the raw material. Agrotechnical requirements state that the impurity of the oil content in the input material should not exceed $3 \%$ for the south of Ukraine and $3.5 \%$ for all regions of the country. Results presented indicate that the content of oil content impurities significantly exceeds the agrotechnical requirements.

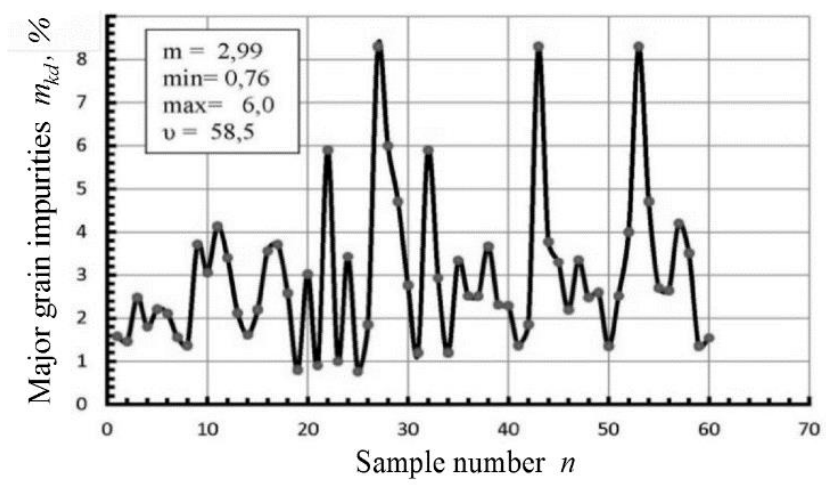

Figure 3. Statistical characteristics of major grain impurities

Major grain impurity $m_{k d}$ in the raw material (Table 3, Fig. 3) was $2.99 \%$, as calculated from the mathematical estimation $m_{k d(\mathrm{sr})}$, the maximum value of $m_{k d(\max )}$ was $6.0 \%$, the minimum value of $m_{k d(\mathrm{~min})}-0.76 \%$, at a standard deviation $\sigma-1.75 \%$ and a coefficient of variation $v-58.49 \%$.

The minor impurity, or husk (Table 3, Fig. 4) was $0.06 \%$, as calculated from the mathematical estimate mld (sr), the maximum value of $m_{l d(\max )}$ was $0.15 \%$, the minimum value of $m_{l d(\min )}-0.01 \%$, at a standard deviation $\sigma-0.039 \%$ and coefficient of variation $v-59.47 \%$. 


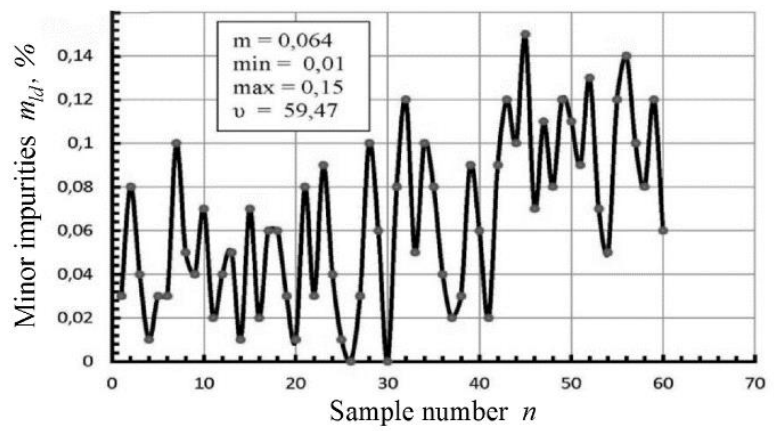

Figure 4. Statistical characteristics of minor impurities.

In the source material (Table 3, Fig. 5), fraction passing through a $3 \mathrm{~mm}$ sieve, $m_{p s}$, was $4.23 \%$, according to the mathematical estimation $m_{p s(\mathrm{sr})}$, while the maximum value of $m_{p s(\max )}$ was $19.13 \%$, the minimum value of $m_{p s(\min )}-0.3 \%$, at a standard deviation $\sigma-3.19 \%$ and coefficient of variation $v-75.59 \%$.

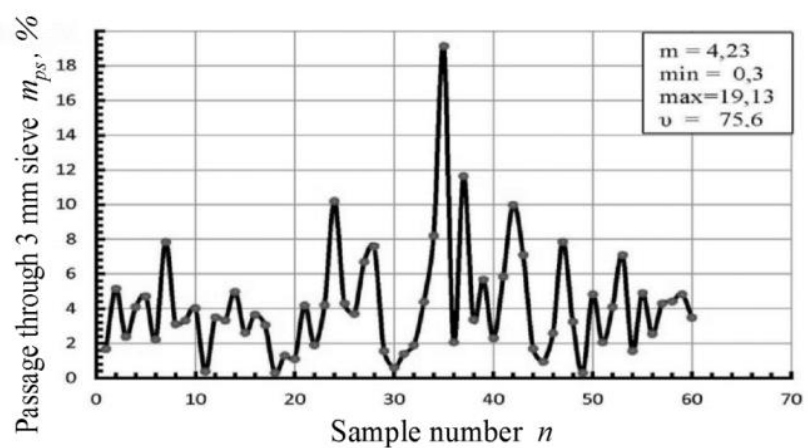

Figure 5. Statistical characteristics of the fraction passing through a $3 \mathrm{~mm}$ sieve.

The grain impurity $m_{s d}$ (Table 3, Fig. 6) was $7.23 \%$, according to the mathematical estimation $m_{s d(\mathrm{sr})}$, while the maximum value of $m_{s d(\max )}$ was $22.48 \%$, the minimum value of $m_{s d(\min )}-2.1 \%$, at a standard deviation $\sigma-3.778 \%$ and coefficients of variation $v-52.20 \%$.

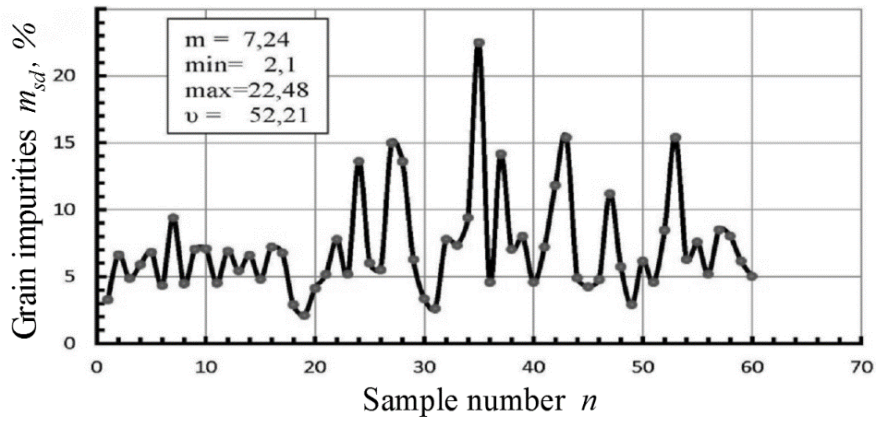

Figure 6. Statistical characteristics of grain impurities. 
Therefore, the purity of the raw material (Table 3, Fig. 7) was $92.76 \%$, according to the mathematical estimation $H_{(\mathrm{sr})}$, while the maximum value $H_{(\max )}$ was $97.1 \%$, the minimum value $H_{(\min )}-84,6 \%$, at a standard deviation $\sigma-3.77 \%$ and coefficient of variation $v-4.07 \%$.

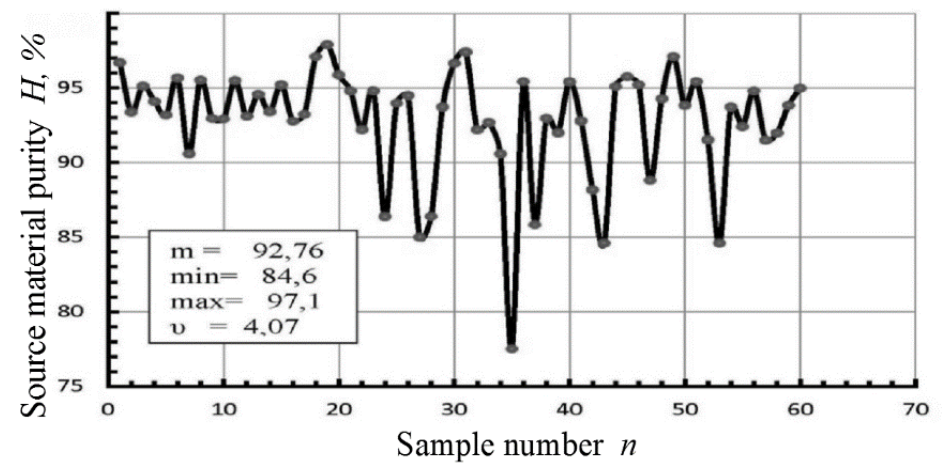

Figure 7. Statistical characteristics of the purity of raw material.

When analyzing the fractions of the components of the sunflower oil raw material components, it can be concluded that purity of the source material is $92.8 \%$, max $-97.1 \%$, min $-84.6 \%$, and impurity $-7.2 \%$, with $\max -22 \%$, and $\min -2.1 \%$.

The analysis of impurities showed that content of major impurities in them was $2.9 \%$, the fraction passing through a $3 \mathrm{~mm}$ sieve $-4.23 \%$, minor impurities $-0.06 \%$. The oil content impurity in the source material was $4.35 \%$. On the other hand, analysis of the total amount of impurities in the sunflower heap: oil impurity in the source material $-37.25 \%$, major impurities $-25.7 \%$, fraction passing through a $3 \mathrm{~mm}$ sieve $-36.5 \%$, minor impurities $0.55 \%$.

The oil content of the waste (impurities) after separation was $15-18 \%$, which allows for obtaining technical oil when such raw material is processed. The MP - 68 No. 7 oil press operating in the Melitopol Oil Extraction Plant (Fig. 8) was used to process the impurities. As a result of processing of 1 ton of grain impurity, 10 liters of technical oil and $990 \mathrm{~kg}$ of fuel material were obtained. 


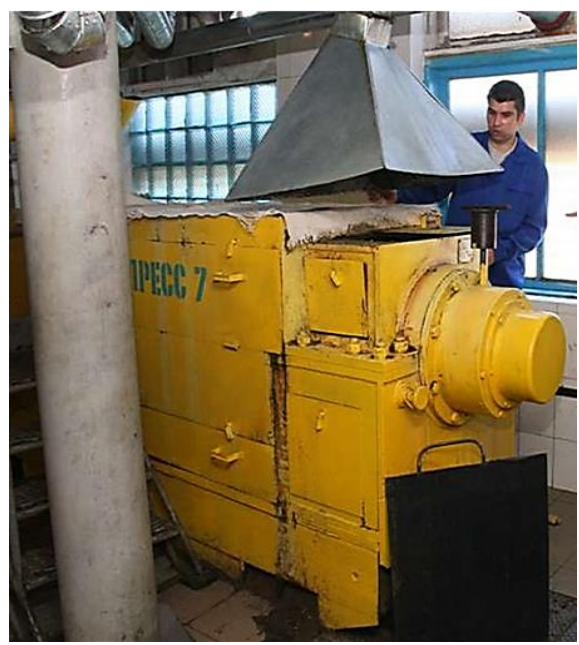

Figure 8. Oil press MP-68 (No. 7).

The practical efficiency of sunflower grain impurities processing is carried out according to the following input data (Table 4):

Table 4.

Input data for economic calculations of the potential of processing sunflower impurities.

\begin{tabular}{|c|c|c|c|}
\hline$n$ & - & the number of working days of the plant per year, (days) & 250 \\
\hline$Q_{d}$ & - & daily volume of processed sunflower raw materials, $\left(\mathrm{t} \cdot \mathrm{day}^{-1}\right)$ & 550 \\
\hline$m_{s d}$ & - & $\begin{array}{l}\text { mathematical estimation of impurities in sunflower } \\
\text { oil raw materials, }(\%)\end{array}$ & 7.28 \\
\hline$m_{\text {to }}$ & - & $\begin{array}{l}\text { mathematical estimation of technical oil in grain } \\
\text { impurities of sunflower raw materials, }(\%)\end{array}$ & 1.0 \\
\hline$C_{s d}$ & - & the price of grain impurities, $\left(\right.$ EUR $\left.\cdot \mathrm{t}^{-1}\right)$ & 29.50 \\
\hline$C_{p m}$ & - & the price of fuels, $\left(E U R \cdot t^{-1}\right)$ & 85.29 \\
\hline$C_{t o}$ & - & the technical oil price, $\left(\mathrm{EUR} \cdot \mathrm{t}^{-1}\right)$ & 705.88 \\
\hline
\end{tabular}

For calculations of the economic efficiency of the sunflower grain impurity processing technology, DSTU 4397: 2005 «Methods of economic evaluation of equipment in the testing stage» was used. According to this standard, the annual economic effect $(E)$ of the processing of impurities in sunflower raw materials can be determined by the following formula:

$$
E=n \cdot Q_{d} \cdot\left(m_{s d} \cdot m_{t o} \cdot C_{t o}+\left(m_{s d}-m_{t o}\right) \cdot C_{p m}-m_{s d} \cdot C_{s d}\right) .
$$

Taking into account the annual load of technological equipment of the Melitopol oil extraction plant, in 250 days, at a daily processing capacity of sunflower oil raw material of 
$550 \mathrm{t} \cdot \mathrm{day}^{-1}$, an annual profit of 560,000 EUR can be obtained from waste impurities processed into fuel materials and technical oil.

\section{Conclusion}

The problem of the depletion of natural energy resources requires the search for alternative fuels. Statistical data analysis showed that a large amount of plant waste is generated annually at the enterprises of agro - industrial complexes. A feature of this waste type is their relatively high energy value, as 1 ton of plant waste is equivalent to 0.625 tons of conventional fuel.

When sunflower oil raw materials get to oil extraction plants, its impurity content according to DSTU 4694: 2006 should not exceed 2\%. According to the mathematical estimation, in fact, the total amount of impurities is $7.29 \%$, in which there is major impurity $-25.7 \%$.

As a part of the total amount of impurity mathematical estimation of an oil - content impurity is $37.25 \%$. This requires further processing of these impurities into fuels and technical oil.

In conclusion, at the annual load of technological equipment of the Melitopol oil extraction plant, in 250 days, at a daily processing capacity of sunflower oil raw material of 550 $\mathrm{t} \cdot$ day $^{-1}$, an annual profit of 560,000 EUR can be obtained from waste impurities processed into fuel materials and technical oil.

\section{References}

Chernyakov, A.V., Koval, V.S., Yatsunov, A.N., Begunov, M.A., Shevchenko A.P., Evchenko, A.V. (2021). Research of a conical pneumatic grain separator with a device for forced light fraction removal. IOP Conference Series: Earth and Environmental Science. 659, 012041.

Choszcz, D.J., Reszczyński, P.S., Kolankowska, E., Konopka, S., Lipiński, A. (2020). The Effect of Selected Factors on Separation Efficiency in a Pneumatic Conical Separator. Sustainability, 12, 3051 .

DSTU 4397:2005. (2004). Methods of economic evaluation of equipment at the testing stage. Kyiv: Sotsinform, 16 (in Ukrainian).

DSTU 4694:2006. (2008). Sunflower. Oil raw materials. Specifications. Enter. 01-03-08. Kyiv: Derzhspozhyvstandart of Ukraine, 19 (in Ukrainian).

Dziedzic, K., Łapczyńska-Kordon, D., Jurczyk, M., Arczewska, M., Wróbel, M., Jewiarz, M., Mudryk, K., Pająk, T. (2021). Solid Digestate - Physicochemical and Thermal Study. Energies, 14(21), 7224

Kharchenko, S., Kovalyshyn, S., Zavgorodniy, A., Kharchenko, F. (2019). Effective sifting of flat seeds through sieve. Eastern-European Journal of Enterprise Technologies, 58(2), 17-26.

Konopka, S., Choszcz, D., Markowski, P. (2017). Optimization of the Separation Parameters and Indicators of Separation Efficiency of Buckwheat Seeds. Sustainability, 9, 2134.

Korys, K.A., Latawiec, A.E., Grotkiewicz, K., Kubon, M. (2019). The Review of Biomass Potential for Agricultural Biogas Production in Poland. Sustainability, 11, 6515.

Kovalenko, N., Kovalenko, V., Hutsol, T., Ievstafiieva, Y., Polishchuk, A. (2021). Economic Efficiency and Internal Competitive Advantages of Grain Production in The Central Region of Ukraine. Agricultural Engineering, 25(1), 51-62.

Mikhailov, E., Postnikova, M., Zadosnaia, N., Afanasyev, O. (2019). Methodological Aspects of Determining Parameters of a Scalper-Type Air-Sieved Separator Airflow. Heidelberg, 1, 133-137. 
Practical potential...

Mikhailov, Ye., Zadosna, N. (2015). Ways to intensify the process of pre-cleaning of grain and oilseeds of sunflower. Proceedings of the Tavria State Agrotechnological University, 5(2), 41-49 (in Ukrainian).

Mikhailov, Ye., Zadosna, N., Mordaryov, P. (2016). Performance indicators of enterprises of the oil processing industry of the Zaporozhye region and ways to increase its efficiency. Bulletin of Sumy National Agrarian University, 10(2), 118-122 (in Ukrainian).

Mykhailov, Ye. (2020). Economic and technical efficiency of sunflower seed processing. Warsaw University of Life Sciences Press. Warszawa. ISBN 978-83-7583-934-0

Sumets, O. (2016). Utilization of industrial waste of oil and fat industry: the need and opportunities. Agricultural and Resource Economics: International Scientific E-Journal, 2(1), 132-141 (in Ukrainian).

Szufa, S., Piersa, P., Adrian, Ł., Sielski, J., Grzesik, M., Romanowska-Duda, Z., Piotrowski, K., Lewandowska, W. (2020). Acquisition of Torrefied Biomass from Jerusalem Artichoke Grown in a Closed Circular System Using Biogas Plant Waste. Molecules, 25, 3862.

Tryhuba, A., Bashynsky, O., Hutsol, T., Rozkosz, A., Prokopova, O. (2020). Justification of Parameters of the Energy Supply System of Agricultural Enterprises with Using Wind Power Installations. 6th International Conference - Renewable Energy Sources (ICoRES 2019). E3S WebConf. 154, 06001.

Tryhuba, A., Hutsol, T., Tryhuba, I., Pokotylska, N., Kovalenko, N., Tabor, S., Kwasniewski, D. (2021) Risk Assessment of Investments in Projects of Production of Raw Materials for Bioethanol. Processes 9(1), 12.

Yermakov, S., Hutsol, T., Rozkosz, A., Glowacki, S., Slobodian, S. (2021). Evaluation of effective parameters of biomass heat treatment in processing for solid fuel. Engineering for Rural Development, 20, 1114-1119.

\section{PRAKTYCZNE MOŻLIWOŚCI WYKORZYSTANIA ZANIECZYSZ- CZEŃ ZBOŻOWYCH W PRZETWÓRSTWIE SUROWCÓW TLUSZCZOWYCH I OLEJOWYCH W PRZEDSIĘBIORSTWACH PRZEMYSLU OLEJOWO-TLUSZCZOWEGO}

Streszczenie. Analiza danych statystycznych wykazała, że w przedsiębiorstwach przemysłu olejowotłuszczowego corocznie powstaje duża ilość odpadów roślinnych, co wymaga ich przetworzenia i wykorzystania. Cechą tego typu odpadów jest stosunkowo wysoka wartość energetyczna, dzięki czemu 1 tona odpadów roślinnych odpowiada 0,625 tony konwencjonalnego paliwa. Zgodnie z oczekiwaniem matematycznym rzeczywista całkowita ilość zanieczyszczeń wynosi 7,29\%, z czego obecność dużych zanieczyszczeń wynosi $25,7 \%$. Jako część całkowitej ilości zanieczyszczeń, matematyczne oczekiwanie zawartości oleju w zanieczyszczeniach wynosi $37,25 \%$. Dlatego wskazane jest przerabianie takich zanieczyszczeń zbożowych na paliwa i olej techniczny. Badania wykazały, że przy rocznym obciążeniu urządzeń technologicznych Wytwórni Oleju Melitopol w ciągu 250 dni przy dobowym przerobie oleju słonecznikowego $550 \mathrm{t} \cdot \mathrm{doba} \cdot{ }^{-1}$ możliwe jest uzyskanie rocznego zysku z przerobu zanieczyszczeń zbożowych na paliwo i techniczne olej w ilości 560000 EUR.

Słowa kluczowe: potencjał praktyczny, przemysł olejów i tłuszczów, surowce do oleju słonecznikowego, zanieczyszczenia zbóż, paliwa 